\title{
Active Learning Methodologies: Challenges for Professors of Two Medical Schools in Rio Grande do Sul, Brazil
}

\section{Metodologias Ativas de Aprendizagem: Desafios dos Docentes de Duas Faculdades de Medicina do Rio Grande do Sul, Brasil}

\author{
Maríndia Biffi(iD \\ Margarita Silva Diercks ${ }^{I I}$ (D) \\ Bárbara Cristina Barreiros ${ }^{I I I}($ (D) \\ Ananyr Porto Fajardo ${ }^{I I}$ D
}

\section{KEYWORDS}

- Evaluation Studies as Topic.

- Active learning.

- Medical Education.

- Public Health.

- Schools Medical.
${ }^{\mathrm{I}}$ Universidade Federal da Fronteira Sul, Passo Fundo, Rio Grande do Sul, Brazil.

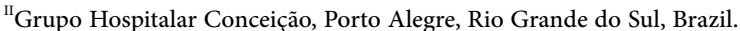

IIISecretaria Municipal de Saúde, São Bernardo do Campo, São Paulo, Brazil 


\section{RESUMO}

\section{PALAVRAS-CHAVE}

- Estudos de Avaliação como Assunto.

- Aprendizagem Ativa.

- Educação Médica.

- Saúde Coletiva.

- Faculdades de Medicina.
Introdução: As Diretrizes Nacionais Curriculares de 2014 dos cursos de Medicina no Brasil propóem a formação de médicos generalistas, humanistas, críticos, reflexivos e éticos, com capacidade para atuar nos diferentes níveis de atenção à saúde, prioritariamente tendo como base dessa formação os cenários do Sistema Único de Saúde. Para atingir esse objetivo, as instituições de ensino devem adotar tecnologias educacionais como as metodologias ativas de aprendizagem, que estimulam o estudante a buscar e construir seu próprio conhecimento. Este estudo tem como objetivos identificar e analisar os desafios que os professores da disciplina de Saúde Coletiva de dois cursos de Medicina do Rio Grande do Sul, no Brasil, enfrentam no uso das metodologias ativas de aprendizagem. Método: $O$ desenho metodológico escolhido foi a pesquisa qualitativa com abordagem de estudo de caso comparativo. Os sujeitos da pesquisa foram os professores da disciplina de Saúde Coletiva de duas universidades. Coletaram-se as informações por meio de questionário sociodemográfico, entrevista semiestruturada e observação semidirigida. O tratamento dos achados pautou-se pela análise temática, e os dados do questionário foram tabulados para exame de sua frequência. Resultado: Os principais achados foram o entendimento, por parte dos docentes, da importância das metodologias ativas nos processos pedagógicos de ensino, a dificuldade de sua inserção pela falta de preparo e a compreensão da necessidade das metodologias ativas de ensino como orientadoras do projeto pedagógico dos dois cursos estudados. Conclusão: As universidades devem ser estimuladas a construir um projeto de educação permanente para o corpo docente, em que essas metodologias sejam assumidas como ponto principal na prática docente, contribuindo também para refletir sobre o modelo de formação que está instituído, assim como repensar a organização do projeto político-pedagógico dos cursos de Medicina.

Received on $1 / 15 / 20$

Accepted on $8 / 31 / 20$

\section{INTRODUCTION}

In June 2014, the National Education Council instituted new National Curricular Guidelines for the Medical Course (DCN-CGM), which constitute mandatory guidelines for the preparation of the curricula adopted by all medical schools in the country.

According to the DCN-CGM ${ }^{1}$, medical undergraduate students must have a general, humanistic, critical, reflective and ethical education, with the capacity to work at the different levels of health care, with social responsibility, commitment to the defense of citizenship and human dignity, and the human being's comprehensive health and having as part of its practice the social determination of the health and disease process.

To achieve this objective, the use of active learning methodologies (ALMs) is suggested as the main reference of the educational process in medical courses ${ }^{2}$. ALMs are considered light-hard educational technologies that provide students' engagement in the learning process and favor the development of critical and reflective skills related to their professional practice ${ }^{3,4}$. It is a process supported by social interactions that allows the acquisition and shared construction of knowledge. Thus, the new formulations and / or understandings of the study objectives are not acquired only through the transmission of content but are produced based on the meaning attributed by the students, conditioned by their experiences, contexts and living conditions ${ }^{5}$. The ALMs are capable of promoting student development towards the training of a competent professional (acquired from expected contents, skills and attitudes), as well as committed to the society in which they live and work ${ }^{5}$.

Active learning is anchored in critical pedagogy and with multiple possible methods, such as Case Study, Problematization Methodology with Maguerez' Arch, Peer Education, Team-Based Learning, ProjectBased Learning and the most widely used in medical courses, ProblemBased Learning ${ }^{6}$. Together with these more complex methods, Active
Teaching and Learning Didactic Strategies are effective resources used by teachers in the student's daily learning. These strategies have two components: Active Teaching-Learning Dynamics (ATLD) and Active Teaching Actions (ATA) ${ }^{7}$.

Active Teaching-Learning Dynamics are techniques used by the teacher for teaching; the Active Teaching Actions, on the other hand, correspond to interventions, postures and attitudes taken by the teacher that enhance active teaching ${ }^{8}$. ATLDs can be implemented in any classroom environment. Among the ATLDs, Gleason et al. ${ }^{8}$ describe: Socratic Questioning, Debates, Fishbowl, Role-Plays, Student Presentations, Games, Research Devices / Audience Response Systems, among others.

In the ALMs, the teacher must forgo the perspective of the master, transmitter of knowledge, and assume the role of facilitator of the teaching process, as the teacher assumes a much more cooperative position than that of holder of the truth $^{6}$, whose main role is stimulating the critical thinking and students' self-learning.

Freitas et al. ${ }^{9}$ affirm that the teacher needs to think about the educational process to structure it; however, generally, these professionals start their careers as educators without pedagogical training for teaching, despite having skills in their specialty. Considering this, the teaching action has been based on the experience of its formation process, being a mirror image of its own teachers, who conducted their classes using the traditional teaching methods $\mathrm{s}^{10}$.

The active methodologies bring direct benefits to the student, as they allow the development of their autonomy, thus forming a creative, reflective and independent professional who uses the knowledge acquired holistically, minimizing the occurrence of a fragmented education ${ }^{7,11,12}$; they provide a contemporary medical training, aimed at the future of the understanding and interventions of the medical professional in a world where the changes resulting from the uninterrupted discoveries challenge 
a set of skills, with an updated and resolutive professional ${ }^{13}$.

For this to occur, the teacher has to increasingly become a manager and advisor of collective and individual pathways ${ }^{14}$. However, this process is permeated by difficulties, as some teachers lack the confidence to implement these educational technologies or consider it risky to share control of the class with students, as well as reports regarding the lack of time to organize activities ${ }^{8,10,15.16}$.

However, an obstacle to apply active methodologies is the necessity for investments and a curricular reform that can be radical regarding the pedagogical process. The implementation of this curricular architecture does not occur abruptly and without extensive planning by higher education institutions $s^{6,7}$, which acquire a fundamental role in sustaining any innovative implemented curricular model. In the curriculum discussed herein, it is important that teachers preferentially dedicate themselves fully to the institution and are prepared to participate in the academic training ${ }^{6}$.

The importance for the teacher to keep updated and follow the advancements, innovations and developments of the political pedagogical project (PPP) is highlighted; however, their lack of knowledge about PPP makes this action a difficult one ${ }^{17}$. Hence the need to qualify educators to understand the reality and contribute to the students' knowledge and learning ${ }^{18}$.

This study was developed at two universities in the countryside of the state of Rio Grande do Sul, Brazil: University 1 (U1), founded in 1970, and University 2 (U2) founded in 2009. Both are organized on a semesterbased course, with vacancies at U1 being filled out through admission tests and U2 through the Unified Selection System (SiSU, Sistema de Seleção Unificada). As it is older, U1 readjusted its PPP in accordance with DCN-CM-2014, when ALMs were added as teaching methodologies. U2, on the other hand, was created based on DCN-CM-2014 and, therefore, ALMs were included in its PPP.

Both universities include the Public Health discipline in all semesters of undergraduate school up to internship, and the syllabi of the two institutions are very similar ${ }^{19,20}$.

This research aimed to identify and analyze the possibilities and difficulties regarding the active learning methodologies of teachers of the Public Health discipline in two medical schools in the countryside of the state of Rio Grande do Sul. The specific objectives were to describe the sociodemographic profile of the assessed teachers, report their experiences and conceptions about active learning, as well as analyze the differences between them and the difficulties the participants faced to implement ALMs.

\section{METHOD}

This is a comparative case study qualitative research ${ }^{21}$.

The population consisted of teachers of the Public Health discipline of the medical course at $\mathrm{U} 1$ and $\mathrm{U} 2$. The inclusion criteria comprised being an active teacher of the Public Health discipline at both universities and having at least one year of teaching experience by March 2018. Those who were on sick leave, study leave, maternity leave or on vacation in the period of data collection, those who taught only practical classes, those who refused to participate in any of the research stages and those who were not interested in participating or did not respond to at least two invitations to participate in the study were excluded. Of a total of 23 teachers from both universities, nine constituted the final sample of this study, and participation was voluntary. Among the 6 women and 4 men who did not accept or did not respond to the invitations, 6 were doctors,
3 were pharmacists and 1 was a nurse; 5 had specialization degrees, 3 had a Master's degree and 2 had a Ph.D. degree.

We considered that there was a saturation of information, resulting in a deeper understanding of the proposed topic, a wide range of empirical and analytical categories, as well as diversity in the process of understanding the perceptions brought on by the preceptors of the two assessed groups ${ }^{22}$.

The information was collected through instruments utilized in different stages:

- Self-administered structured questionnaire for sociodemographic characterization, professional trajectory and the participants' training process, sent by e-mail together with the Free and Informed Consent Form (FICF) to all potential research subjects. Following the acceptance to participate and after signing the FICF, the teachers filled out the questionnaire.

- Semi-directed observation of classes taught by the teachers participating in this study, aiming to describe the teachers' experience with ALMs.

- $\quad$ Semi-structured individual interview with guiding questions related to the objectives of the study, which took place after the classes were observed. All interviews were recorded and later transcribed in full. The interviews were conducted by the main researcher, in person, respecting the participants' confidentiality and privacy.

Two different groups were created to compare the results: group A corresponds to U1 teachers and received the letter "A", just as U2 teachers received the letter " $\mathrm{B}$ ", all selected at random. The information recorded in the self-administered structured questionnaires was tabulated to assess its frequency. The semi-directed observations were recorded, read and categorized to list the main topics. These topics were reapproached in the semi-structured interviews aiming to identify the contradictions between theory and practice.

The individual semi-structured interviews, after their verbatim transcription, were read and summarized according to the criteria of exhaustiveness, representativeness and relevance of the content of the obtained responses ${ }^{22}$. During the assessment of the material, the individual product was evaluated, reaching categories of expressions that were representative of the topic and its approach. At this moment, 33 empirical categories were identified, which were grouped into three categories. Of the categories resulting from the grouping, three categories of analysis were selected, which were investigated based on the reference concepts of the ALM, as shown in Chart 1.

The study followed Resolution $466 / 201223$ and was approved by the Research Ethics Committee of Grupo Hospitalar Conceição according to Opinion 16-119, CAAE: 89303118.3.0000.5530.

Two categories of analysis will be described In this article: Knowledge and experiences of ALMs by the teachers and Possibilities and difficulties of teachers' professional practice with Active Learning Methodologies

\section{RESULTS AND DISCUSSION}

Characterization of the subjects

The information obtained from the sociodemographic questionnaire is systematized in Chart 2. The predominant age group is from 37 to 56 years old, with the female sex being more prevalent. Regarding the

REVISTA BRASILEIRA DE EDUCAÇÃO MÉDICA

3 44 (4) : e145; 2020 


\begin{tabular}{|c|c|c|}
\hline \multicolumn{3}{|c|}{$\begin{array}{l}\text { Chart } 1 \\
\text { f the analysis categories }\end{array}$} \\
\hline Empirical Categories & Category Grouping & Analysis Categories \\
\hline $\begin{array}{l}\text { Popular Education } \\
\text { PBL (Problem Based Learning) } \\
\text { Peer Education } \\
\text { PjBL (Project Based Learning) } \\
\text { TBL (Team-based learning) }\end{array}$ & Types of active methodologies & $\begin{array}{c}\text { Knowledge and experiences of ALMs by } \\
\text { teachers }\end{array}$ \\
\hline $\begin{array}{l}\text { ALM - Institutional Policies } \\
\text { ALM - New Pedagogical Processes } \\
\text { ALM - Student } \\
\text { ALM - Teacher training } \\
\text { ALM - Teacher } \\
\text { ALM - Student assessment difficulty } \\
\text { ALM - Potentialities } \\
\text { ALM - Practical field } \\
\text { ALM - Teaching practice } \\
\text { ALM - Macro Historical Process } \\
\text { ALM - Micro Historical Process }\end{array}$ & Active Learning Methodologies & Active Learning Methodologies \\
\hline $\begin{array}{l}\text { Time-related difficulty in class organization } \\
\text { Structural difficulty (didactic material, structure, equipment, internet) } \\
\text { Teachers' financial difficulties } \\
\text { Difficulties with Students } \\
\text { Teacher Training Difficulty } \\
\text { Teaching Tools + Telemedicine } \\
\text { Current professional practice } \\
\text { Professional Trajectory } \\
\text { Historical Model of Medical Education } \\
\text { Teacher Training Model } \\
\text { Student Changes } \\
\text { Teachers' profile changes } \\
\text { Pedagogical Process - Pedagogical activities in teaching } \\
\text { Preparation of classes by teachers } \\
\text { Professional achievement } \\
\text { Student Achievement }\end{array}$ & Current professional practice & $\begin{array}{c}\text { Possibilities and difficulties of teachers' } \\
\text { professional practice with Active Learning } \\
\text { Methodologies }\end{array}$ \\
\hline
\end{tabular}

Source: Prepared by the authors 2019.

\begin{tabular}{|c|c|c|c|c|c|c|c|c|c|}
\hline \multicolumn{10}{|c|}{ Chart 2} \\
\hline $\begin{array}{c}\text { A -U1 } \\
\text { B -U2 } \\
\text { Age / Gender }\end{array}$ & Training & Year & Master's Degree & $\begin{array}{l}\text { Ph.D. } \\
\text { Degree }\end{array}$ & $\begin{array}{c}\text { Employment } \\
\text { - Longer } \\
\text { Workload }\end{array}$ & $\begin{array}{c}\text { Type of employment } \\
\text { bond }\end{array}$ & $\begin{array}{l}\text { Salary range } \\
\text { - minimum } \\
\text { wages }\end{array}$ & $\begin{array}{c}\text { WL - } \\
\text { Weekly } \\
\text { hours }\end{array}$ & $\begin{array}{c}\text { Year of } \\
\text { Admission }\end{array}$ \\
\hline $\begin{array}{l}\text { A1 / } 56 \\
\text { Female }\end{array}$ & Nursing & 1998 & $\begin{array}{l}\text { Health management } \\
\text { In progress }\end{array}$ & & Teaching & Contract & $\begin{array}{l}\text { Between } 3 \\
\text { and } 6\end{array}$ & 23 & 2010 \\
\hline $\begin{array}{l}\text { A2/ } 40 \\
\text { Female }\end{array}$ & Dentistry & 2002 & $\begin{array}{l}\text { Public Health } \\
\text { Concluded }\end{array}$ & $\begin{array}{l}\text { Public } \\
\text { Health }\end{array}$ & Teaching & Selection & $\begin{array}{l}\text { Between } 3 \\
\text { and } 6\end{array}$ & 22 & 2010 \\
\hline $\begin{array}{l}\text { A3 / } 38 \\
\text { Female }\end{array}$ & Physiotherapy & 2004 & $\begin{array}{l}\text { Epidemiology } \\
\text { Concluded }\end{array}$ & & Teaching & Exam - private service & $\begin{array}{l}\text { Between } 3 \\
\text { and } 6\end{array}$ & 26 & 2015 \\
\hline $\begin{array}{l}\text { A4 / } 40 \\
\text { Female }\end{array}$ & Medicine & 2003 & $\begin{array}{l}\text { Human Aging } \\
\text { Concluded }\end{array}$ & & Teaching & Civil service exam & $\begin{array}{l}\text { Between } 3 \\
\text { and } 6\end{array}$ & 20 & 2009 \\
\hline $\begin{array}{l}\text { B1 / } 52 \\
\text { Female }\end{array}$ & Philosophy & 1999 & $\begin{array}{c}\text { Education - } \\
\text { emphasis on Health. } \\
\text { Concluded }\end{array}$ & $\begin{array}{l}\text { Education } \\
\text { - emphasis } \\
\text { on Health. }\end{array}$ & Teaching & Civil service exam & $\begin{array}{l}\text { Between } 6 \\
\text { and } 9\end{array}$ & $40 \mathrm{ED}$ & 2013 \\
\hline $\begin{array}{c}\text { B2 / } 43 \\
\text { Male }\end{array}$ & Medicine & 2004 & $\begin{array}{l}\text { Human Aging } \\
\text { In progress }\end{array}$ & & Assistance & Civil service exam & $\begin{array}{c}\text { Between } 3 \\
\text { and } 6\end{array}$ & 20 & 2016 \\
\hline
\end{tabular}




\begin{tabular}{|c|c|c|c|c|c|c|c|c|c|}
\hline \multicolumn{10}{|c|}{$\begin{array}{c}\text { Chart } 2 \\
\text { Continuation. }\end{array}$} \\
\hline $\begin{array}{c}\text { A -U1 } \\
\text { B -U2 } \\
\text { Age / Gender }\end{array}$ & Training & Year & Master's Degree & $\begin{array}{l}\text { Ph.D. } \\
\text { Degree }\end{array}$ & $\begin{array}{c}\text { Employment } \\
\text { - Longer } \\
\text { Workload }\end{array}$ & $\begin{array}{c}\text { Type of employment } \\
\text { bond }\end{array}$ & $\begin{array}{l}\text { Salary range } \\
\text { - minimum } \\
\text { wages }\end{array}$ & $\begin{array}{l}\text { WL - } \\
\text { Weekly } \\
\text { hours }\end{array}$ & $\begin{array}{c}\text { Year of } \\
\text { Admission }\end{array}$ \\
\hline $\begin{array}{c}\text { B3 / } 36 \\
\text { Male }\end{array}$ & Medicine & 2009 & $\begin{array}{l}\text { Professional Master } \\
\text { in Family Medicine } \\
\text { In progress }\end{array}$ & & Assistance & Civil service exam & $\begin{array}{l}\text { Between } 6 \\
\text { and } 9\end{array}$ & 20 & 2017 \\
\hline $\begin{array}{l}\text { B4 / } 40 \\
\text { Female }\end{array}$ & Medicine & 2005 & $\begin{array}{c}\text { Human Aging } \\
\text { Concluded }\end{array}$ & & Teaching & Civil service exam & $\begin{array}{c}\text { Between } 6 \\
\text { and } 9\end{array}$ & 40 & 2017 \\
\hline $\begin{array}{l}\text { B5/ } 41 \\
\text { Male }\end{array}$ & Medicine & 2002 & $\begin{array}{c}\text { Epidemiology } \\
\text { Concluded }\end{array}$ & & Management & Specific selection & More than 9 & 40 & 2017 \\
\hline
\end{tabular}

Legend: WL: workload; ED: exclusive dedication.

Source: Prepared by the authors 2019.

educational institution, four were teachers at U1 (a nurse, a physiotherapist, a physician and a dentist) and five at $\mathrm{U} 2$ (a philosopher and four physicians), showing that the training areas bring a multidisciplinary view to the teaching of the collective health discipline. As for postgraduate studies, two had a Ph.D. degree, four had a Master's degree and the others are studying to obtain a Master's degree. As for the time working as a teacher at the current institution, it ranges between one and nine years, ranging between one and two years for the majority, that is, most are at the beginning of their careers. The salary range of participants varies, with five of them receiving between three and six minimum wages (MW-2018), three receiving between six and nine MW and only one receiving more than nine MW.

Six participants considered teaching as their main occupation, but the workload dedicated to the job varies, and only one worked with exclusive dedication. Most teachers at U1 have a shorter workload dedicated to teaching than teachers at $\mathrm{U} 2$, where two of them work 40 hours a week. However, they still find it difficult to exercise this function:

So, it is hard work, demands time and sometimes people do not have time due to financial reasons, because they are working on other things or they do not see the motivation [...] (A1).

As stated by Mesquita, Meneses et al. ${ }^{15}$, it is necessary for the professional to have a critical reflection on the exercise of teaching in order to value the teaching profession, the knowledge of teachers, their collective work at the institutions as spaces for continuing education, as well as for the recognition of the teacher as a researcher and knowledge producer. According to the participants,

I think he is an advisor, he is a stimulator [...] (A1).

Our role is to be a researcher during our entire life, because we become more facilitators of the process, but we must always be very up-to-date, we need to have the mastery of the methodology and also of the content, because in order to help them ask the questions, we must know what the key content is, so we are able to guide them [...] (B1).

Regarding the other sociodemographic characteristics, no significant differences were found between the two groups. Below, the categories of analysis that will be assessed in greater depth according to the study objectives are described, exploring the teachers' perceptions regarding the practice of ALMs.

\section{Knowledge and experience of ALMs}

The profile of the Brazilian teacher of medical courses is that of professionals who teach without necessarily having pedagogical knowledge ${ }^{6}$, and this characteristic is identified in this study, which shows the lack of training in ALMs. This scenario is consistent with a practice in which the teachers teach their classes according to their convictions and repeat models experienced during their training ${ }^{17}$. However, a teacher's training cannot be restricted to participation in occasional courses, but must necessarily include training, supervision and evaluation programs that are carried out in an integrated and permanent manner ${ }^{15}$.

If I tell you that I have experience with active methodologies, I have little [...] (A2).

So I end up observing what the other teachers worked on, what I learned, what I read and then applied [...] (A3).

I have no training in active methodologies. What I have is selftaught training (B3).

[...] I took a Distance Learning course for the institution's teachers related to practices of active methodologies, but otherwise, regarding active methodology, nothing (B4).

A group of teachers of the assessed discipline in both universities reports that they feel lack of knowledge, uncertainties and difficulties in the use of active methodologies in their teaching practice in health:

[...] You have to make this as dynamic as possible, as clear as possible, whether using someone's case from a BHU or from a visit they made (A3).

[...] I use dialogued exposition, sometimes we have to use this technique, I also guide a directed study and then we carry out a debate, like a seminar; in short, it is quite diverse, sometimes I use short videos [...] (B1).

We try to adopt a methodology that we consider to be an active

\begin{tabular}{|l|l} 
REVISTA BRASILEIRA DE EDUCAÇÃO MÉDICA \\
\hline $4(4):$ (45; 2020
\end{tabular}

5 44 (4) : e145; 2020 
methodology [...] the first meetings are face-to-face, theoretical meetings, with lectures, readings of some articles, materials, there are also some videos that we bring to classes. [...] So they go to the Units, come back, organize the materials and we have a debate (B3).

In their practice, teachers need to think about the educational process in order to structure it, aiming to provide reflections, skills and actions. This structuring is the result of planning, which is directly related to the choice of content, activities, available resources and the methodology to be used ${ }^{9}$.

[...] You have to follow a schedule, follow a syllabus, a teaching plan, but always with a dialogue, no matter how much it is a lecture $[. .$.$] (A3).$

[...] I am trying to provide, merge, traditional lectures, but always making them reflect and always trying to permeate these traditional classes with clinical cases [...] (B2).

[...] The first meetings are face-to-face, theoretical meetings, with lectures $[. .$.$] (B3).$

It can be perceived in the participants' speeches, whether they are doctors or not, that they have the intention to use ATLD; however, this becomes fragmented and interspersed with traditional lectures, during which the transmission of knowledge occurs, and the use of the new tools aims only at bringing the students' attention back to the class, in an attempt to make it more interesting ${ }^{24}$.

There is a simulated jury, which is another way to bring SUS into it. I also use a methodology that I do not know what it is called, I learned as GVGO (Verbalization Group and Observation Group), but to study, for instance, SUS legislation, each group studies one of the laws [...]. (B1).

Here in Medicine, we use TBL (Team-based Learning) a lot. We use post-tests, which also constitute a way to remember the class content [...] it has been very interesting to work with playful activities, the games that give different ideas to use other different active methodologies, because otherwise we always use the same old ones $[\ldots]$ (B2).

I use a little bit of PBL (Problem Based Learning), here I have these clinical cases that I created to address the policy [...] (B5).

It can be observed that teachers from $\mathrm{U} 1$ have some knowledge about what types of ALMs exist and how to use them. However, the curriculum is still fragmented, and it is up to the teachers to decide which teaching strategies they are going to use in class. At U2, however, there is a greater lack of knowledge, and there is still a lot of conceptual misunderstanding between ALMs, active teaching strategies and ATLD, which is in line with what Freitas et al. ${ }^{9}$ reported.

Regarding the observations made in the classroom, there was a large number of students per class, which in itself makes active learning difficult and demonstrates that the curricular structure is not supported by the ALM, since the active pedagogical processes should preferably be organized in small groups of 6 to 8 students with a facilitator. The most often used resources were audiovisuals with a projector and video, seminars, case discussions and the development of products related to the discipline contents; however, the lectures stand out, with a traditional organization, in which the teacher plays the role of 'knowledge holder' and the student is the listener.

Even with the recognition of pedagogical trends that guide the teaching-learning process and some individual attempts by teachers to include ATLD during class, the influence of the traditional teaching method, centered on the teacher and the content, remains a strong part of the everyday life of teachers working with the collective health discipline in both universities. It is possible to observe that there is no methodological structure supported by ALMs in the discipline, differently from what is described in the PPP of both universities.

Intervening in this process of professional naturalization requires a systematized reflection energy, based on the deconstruction of the experience. The teachers only change their practices when they are able to reflect on themselves and on their training ${ }^{25}$, aiming at leaving the perspective of the master, the transmitter of knowledge to assume a role of facilitator of the teaching process, since the teachers, in the ALMs, assume a much more cooperative position than that of holder of the truth ${ }^{6}$. Their main role is to stimulate students' critical thinking and self-learning.

Possibilities and difficulties of teachers' professional practice with Active Learning Methodologies

Regarding the possibilities, the two groups of teachers point out that ALMs are important for both the teacher and the student:

The potential is to change this classic teaching model a little bit, in which the teachers are right when talking [...] I think that in this exchange there can be a very nice gain for the student, to be able to contribute more, having to take the initiative; it is a different form of learning, in which they have to mobilize themselves. I think it stimulates more creativity, student leadership, [...] (A3).

I think it has a huge potential to turn the students into protagonists, to awaken the desire, the willingness to study. It means being the builder of your own knowledge, of showing commitment, of being fascinated, because knowledge is something that generates a lot of pleasure, [...] the search for wisdom is something that fascinates and gives a lot of pleasure, so if we can challenge the students to do that, they become fascinated and we see it [...] (B1).

Xavier, Oliveira et al. ${ }^{18}$ address this perception and affirm that the teacher's role is to facilitate the teaching process, encouraging the learners to choose relevant solutions for each problem-situation, as these new ways of working with knowledge in higher education aim to break with the traditional model of teaching.

Freitas et al. ${ }^{9}$ state that the relationship between teacher and student allows the exchange of knowledge, being an essential condition for the teaching-learning process, which makes the educational process a dynamic one and gives it meaning. The teachers also experience changes because, by meeting and getting closer to students, they can review their ideas and, above all, reflect on their values and judgments. From this perspective, the teacher increasingly becomes a manager and advisor of collective and individual, predictable and unpredictable pathways, in a more open, 
creative and innovative construction ${ }^{14}$, as can be observed in the following excerpts from participants of both universities:

\section{[...] Extremely gratifying, I cannot see myself far from it (A4).}

[...] We meet, they come to thank me for these small gestures that I think are those from a dedicated educator, which we must have (B1).

[...] we also feel more accomplished as teachers. [...] I think the teachers feel better, I think they feel more accomplished, that was the impression I had today when I left the class (B5).

However, pedagogical innovations require time, effort, human and structural resources. It is necessary to have a greater workload to consider and carry out the actions required by the ALMs; the effort is a condition to reach the goals established in the innovation, and sometimes the necessary resources are scarce or nonexistent to meet the demands that ALMs bring, such as for instance, more teachers and more classrooms to be able work in small groups, an essential aspect of the pedagogical process of active methodologies. However, although their lack can be an obstacle to innovation, their presence is also no guarantee of its attainment ${ }^{16}$.

The lack of time for the teacher to plan and prepare the classes is present in the statements of the teachers from both institutions, as only one of them works with exclusive dedication. Almeida and Batista ${ }^{26}$ states that the depreciation of the teacher, little institutional recognition, low wages and, consequently, lack of time due to the need to compensate the financial gain with other activities, often impairs the teacher's development process.

[...] To prepare a lecture, it will take time for you to do it, it is ready, and you will always use the same one. An Active Methodology is not quite like that, you may even have the material you will need ready, but maybe you will have to correct something later, or prepare the entire material for that class. [...] I think that is more or less what I said, about the teacher needing time to do this (A3).

[...] I think it takes a lot more time to prepare the class than a normal theoretical lecture and, sometimes, we end up sort of settling down because there is a limited time for class creation and it is not possible, but it exists, I think this possibility exists (B4).

This study also shows the lack of experience of the Public Health discipline teachers, with their statements demonstrating the lack of training to teach and the lack of planning to exercise this activity. In general, these professionals enter the career of educators without having had pedagogical training for teaching, despite their skill in their specialty ${ }^{18}$ :

[...] When I started teaching, I started with Internship Supervision, [...] then they invited me to teach and I said, "but I don't know how to teach", "but it is easy, we'll help you" (A3).

I had not had formal teaching experience before this one (B3).

Another difficulty brought by the professionals is the student's role in the active learning process. Gleason et al. ${ }^{8}$ point out as potential barriers the lack of interest in the students' disposition or training to participate in active learning, as traditional lectures, with their unidirectional transmission of information, demand little effort on their part. Active learning is a departure from the passive modality, as it requires students to think critically about the process. Consequently, some may resist the active learning. This was observed in the classroom, in which students were used to the practice of being just listeners and, when asked to contribute, few were those who participated:

Sometimes there is some resistance, but ready-made classes are what they are used to [...] (A1).

[...] Because the student is used to sitting and receiving information only, then you come and break the paradigm [...] (A3).

So they want everything ready, chewed up. If it can be placed, inserted into their brains, it seems better (B3).

[...] The question of motivating students to participate, as the active methodology demands participation and if the student is not inclined to collaborate, it gets a little more complicated [...] (B4).

This lack of availability by the students to participate in active learning processes can occur at the beginning of the process but allowing them to have a clear understanding of the purpose of these activities and establishing roles and responsibilities can improve their participation in classes and their performance ${ }^{8}$.

As stated by Xavier, Oliveira et al. ${ }^{18}$ about the teacher-student relationship, the addressed contents in the teaching-learning process must be dynamic and favor a closer relationship between teachers and students, as well as being able to contribute to the formation of critical and reflective professionals. Therefore, the teacher must include the students in different situations, addressing prior knowledge, diversifying the scenarios and considering the practice to facilitate the construction of new knowledge ${ }^{18}$. Additionally, ALMs promote the necessary conditions for activities that encourage the development of students' distinct thinking skills and enable the teacher to act in those situations that promote autonomy, replacing, whenever possible, the evidently controlling situations ${ }^{9}$.

There are no facilities for teachers who take on this pedagogical challenge ${ }^{15}$, since the use of active methods requires greater involvement/ knowledge of the teaching-learning process, unpredictability and variability, as they are centered on the student, flexibility, the sharing of power and the joint construction of knowledge ${ }^{16,26}$.

These aspects lead us to think about how to improve this process. Teachers suggest that training courses be held, aiming at qualifying them for activities consistent with the active learning methods. They also emphasize training in small groups, following the active methodologies, in line with the study by Xavier, Oliveira et al. ${ }^{18}$. However, when comparing the two universities, it was observed that $\mathrm{U} 1$ promotes training courses, however infrequent, but only with theoretical approaches of the several existing active methodologies, without correlating them to the teachers' experiences and practices. At $\mathrm{U} 2$, training moments are very sporadic, without the purpose of training teachers for their daily practice.

[...] To train Public Health teachers in this issue of active methodologies (B2).

REVISTA BRASILEIRA DE EDUCAÇÃO MÉDICA

$744(4):$ e145; 2020 
Mainly to promote, promote continuing education for the teacher $[\ldots](B 4)$.

This practice is consistent with what Mesquita, Meneses et al. ${ }^{15}$ says, as continuing education should be offered, indicating that it is necessary to provide training moments for all those involved in the educational process. The objective is to train an active professional, prepared for the exercise of teaching, mainly in order to meet the needs of understanding pedagogies, methodology and methods that favor a more critical, reflective learning, articulated with reality. However, when thinking about continuing education, our view aims at the institution and how much it supports them in this process:

[...] We have some training for teachers here at the Medical School, which I think was a very important advance (A1).

[...] an afternoon of training will not give a new meaning to the practice, so we are actually talking about a Permanent Education Policy at the university, in the institutions, so that I could learn something during a six-month training and apply it (B5).

It is necessary for the institutions to allow teachers to rethink and modify their educational practice, considering the need to train teachers capable of instructing critical, reflective and questioning subjects, in response to the needs of society ${ }^{15}$.

The improvement of teachers' training / development practices in the health area must be part of a broader institutional project, which implies assuming it as a permanent process ${ }^{26}$. When analyzing the teachers' reports, it was observed that neither of the two institutions promotes this training, providing their teachers with sporadic training only, without stimulating spaces for joint reflection on established pedagogical practices, or to reformulate these practices, much less to share experiences.

In agreement with Almeida and Batista $^{26}$, that the management of medical schools must be carried out by leaders capable of planning and managing the curriculum, and ensuring that teaching and student activities are carried out with motivation and that the expected results are achieved, the following excerpt considers the following:

[...] doing the training and I think they have also to encourage the teaching staff, allowing the training of the staff, show the possibilities of both structural and physical resources, as well as human resources to support these methodologies and there is also the entire managerial issue, of putting some things regarding the question of the Political Pedagogical Plan, the Teaching Plan (A3).

\section{FINAL CONSIDERATIONS}

The current training of medical professionals recommended by the DCN-CGM-2014 requires curricular changes and pedagogical processes supported by ALMs in higher education institutions. In both assessed Medical Schools, the PPPs propose to train a doctor who develops critical and reflective thinking and "with the capacity to act at different levels of health care, with actions aimed at the promotion, prevention, recovery and rehabilitation of health, at the individual and collective level"1,6. However, a contradiction was observed between what is proposed in the PPPs and what happens in the daily life of the assessed medical courses. Therefore, there is a discrepancy with the DCN-CGM:
"The Undergraduate Medical Course will have a pedagogical project centered on the student as a subject of learning and supported by the teacher as a facilitator and mediator of the process, aiming at the integral and adequate training of the student, articulating teaching, research and extension, [...] using methodologies that favor the student's active participation in the construction of knowledge and the integration between the contents ${ }^{31,11}$.

It can be observed that the changes in the guidelines have proposed changes in the characteristics of teachers and in the development of their pedagogical practices. However, many teachers have no experience with ALMs; they do not know how to use it in their daily teaching practice. Therefore, they end up using mixed processes, with ATLD and traditional teaching, which culminates in difficulties regarding their inclusion in the pedagogical process. All teachers report the important role of ALMs for student training but claim they still need to prepare themselves to put them into practice.

Therefore, the plans for teacher development anchored on permanent education will help to support the teachers on their needs and difficulties regarding training in ALMs, as well as offering a moment to exchange experiences about their daily practices.

There is a concern regarding what type of medical professional is being trained and whether curriculum guidelines are being met. It has been proven that ALMs are essential for the training of these professionals, mainly by encouraging students to have a critical reflective attitude, to learn from practice and, mainly, taking into account all the previous knowledge of these students, to encourage them to leave the university with the skill of 'learning to learn'.

When analyzing the PPP of each of the studied universities, there was a discrepancy with what is proposed in the DCN-CGM, as the curricula of both institutions are still fragmented - U1 uses the traditional method, divided into disciplines, while $\mathrm{U} 2$ has a modular organization.

The PPP of both universities mentions the ALMs; however, when considering the teachers' experienced and observed practices, one can conclude that the classes assumed an expository format, with a predominantly traditional pedagogical reference. As there is a discrepancy between what is registered in the PPP and the classroom, it is up to the teachers to decide what type of methodology they will use in their pedagogical meetings, since the curriculum instituted in the two universities is not concretely structured on the ALMS, but on a traditional pedagogy that allows the use of ATLD. On the other hand, it is evident that the courses coordination supports and encourages ALMs but does not place them as the main methodology for student training. It was also observed that the PPP of U2 is more integrated, but, it is more traditional in terms of teacher training and teaching practice, in contrast to $\mathrm{U} 1$, which has a traditional curriculum regarding disciplines and teachers, with a more active practice, with more comprehensive institutional encouragement and support. This contradiction between theory (PPP) and practice (traditional curriculum, pedagogical process, training of teachers and medical students) makes it difficult and puts stress on teachers' teaching practice and the training of the future doctors, as demonstrated by the curriculum guidelines.

Thus, in addition to teacher training, there are other institutional actions that can be explored with the adoption of ALMs, especially those

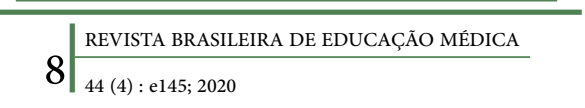


aimed at restructuring the PPP and continuous collaboration to provide teachers with the means to apply ALMs in their classes.

It is also observed that it is necessary to broaden the discussion on the topic, especially regarding the role of management and the pedagogical training necessary for the effectiveness of ALM-based teaching in health, which, even with all the guiding and restructuring guidelines of this teaching methodology, do not guarantee that the training takes place as recommended.

Therefore, universities should be encouraged to have a permanent educational project with the definition of which theoretical structure they will utilize, in which ALMs are placed as the main point in teaching practice, thus also contributing to rethink the training model and the pedagogical political project that is implemented.

\section{ACKNOWLEDGMENT}

The authors would like to thank the Postgraduate Program in Technology Assessment for SUS of Grupo Hospitalar Conceição (GHC) for the support in all stages of the research development, from the project design to the publication of the article in this journal.

\section{REFERENCES}

1. Brasil. Resolução CNE/CES n 3/2014. Institui as Diretrizes Curriculares Nacionais do Curso de Graduação em Medicina e dá outras providências. Diário Oficial da União, Brasília, DF; 23 jun 2014; Seção 1, p. 8-11.

2. Nespoli G. Os domínios da tecnologia educacional no campo da saúde. Interface Comum Saúde Educ. 2013;17(47):873-44.

3. Almeida MJ, Campos JJB, Turín B, Nicoletto SCS, Pereira LA, Rezende, LR, et al. Implantação das Diretrizes Curriculares Nacionais na Graduação em Medicina no Paraná. Rev Bras Educ Med. 2007;31(2):156-65.

4. Cotta RMM. Descentralização das políticas públicas de saúde: do imaginário ao real. Viçosa: UFV; 1998.

5. Batista NA, Vilela RQB, Batista SHSS. Educação médica no Brasil. São Paulo: Cortez; 2015.

6. Machado CDB, Wuo A, Heinzle M. Educação médica no Brasil: uma análise histórica sobre a formação acadêmica e pedagógica. Rev Bras Educ Med. 2018;42(4):66-73.

7. Farias PAM, Martini ALAR, Cristo CS. Aprendizagem ativa na educação em saúde: percurso histórico e aplicações. Rev Bras Educ Med. 2015;39(1):143-58.

8. Gleason BL, Peeters MJ, Resman-Targoff BH, Karr S, McBane S, Kelley $\mathrm{K}$, et al. An active-learning strategies primer for achieving abilitybased educational outcomes. Am J Pharm Educ. 2011;75(9):186.

9. Freitas DA, Santos EMF, Lima LVS, Miranda LN, Vasconcelos EL, Nagliate PC. Saberes docentes sobre processo ensino-aprendizagem e sua importância para a formação profissional em saúde. Interface (Botucatu). 2016;20(57):437-48.

10. Machado MMBC, Sampaio CA, Macedo SM, Figueiredo MFS, Rodrigues Neto JF, Lopes IG, et al. Reflexões e significados sobre competências docentes no ensino médico. Avaliação. 2017; 22(1):85-104.

11. Conceição CV, Moraes MAG. Aprendizagem cooperativa e a formação do médico inserido em metodologias ativas: um olhar de estudantes e docentes. Rev Bras Educ Med. 2018; 42(4):115-22.

12. Gomes AP, Rego S. Transformação da educação médica: é possível formar um novo médico a partir de mudanças no método de ensinoaprendizagem? Rev Bras Educ Med. 2011;35(4):557-66.

13. Maia JA. Metodologias problematizadoras em currículos de graduação médica. Rev Bras Educ Med. 2014;38(4):566-74.

14. Moran J. Mudando a educação com metodologias ativas. In: Souza CA, Morales OET, organizadores. Convergências midiáticas, educação e cidadania: aproximações jovens. Ponta Grossa: Proex/UEPG, 2015.

15. Mesquita SKC, Meneses RMV, Ramos DKR. Metodologias ativas de ensino/aprendizagem: dificuldades de docentes de um curso de enfermagem. Trab Educ Saúde. 2016;14(2):473-86.

16. Jerez O, Silva C, Hasbún B, Cevallos MR. Innovando en educación superior: experiencias clave en Latinoamérica y el Caribe 2016-2017. Santiago: Facultad de Economía y Negocios, Universidad de Chile; 2017.

17. Tsuji H, Silva RHA. Aprender e ensinar na escola vestida de branco: do modelo biomédico ao humanístico. São Paulo: Phorte; 2010.

18. Xavier LN, Oliveira GL, Gomes AA, Machado MFAS, Eloia SMC. Analisando as metodologias ativas na formação dos profissionais de saúde: uma revisão integrativa. Sanare. 2014;13(1):76-83.

19. Universidade Federal da Fronteira Sul. Projeto Pedagógico do Curso de Graduação em Medicina. Passo Fundo, RS; maio 2013.

20. Universidade de Passo Fundo. Projeto Pedagógico do Curso de Medicina: atualização Medicina Integral 5236. Passo Fundo, RS; 2017. [Documento interno].

21. Yin RK. Estudo de caso: planejamento e métodos. 3a ed. Porto Alegre: Bookman, 2005.

22. Minayo MCS. Amostragem e saturação em pesquisa qualitativa: consensos e controvérsias. Rev Pesq Qual Abr. 2017;5(7):1-12.

23. Brasil. Resolução $n^{\circ} 466$, de 12 de dezembro de 2012. Aprova as diretrizes e normas regulamentadoras de pesquisas envolvendo seres humanos. Brasília, DF; 12 dez 2012.

24. Marin MJS, Lima EFG, Paviotti AB, Matsuyama DT, Silva LKD, Gonzalez C, et al. Aspectos das fortalezas e fragilidades no uso das metodologias ativas de aprendizagem. Rev Bras Educ Med. 2010;34(1):13-20.

25. Cunha MI. Docência na universidade, cultura e avaliação institucional: saberes silenciados em questão. Rev Bras Educ. 2006;11(32):258-71.

26. Almeida MTC, Batista NA. Ser docente em métodos ativos de ensino-aprendizagem na formação do médico. Rev Bras Educ Med. 2011;35(4):468-76.

\section{AUTHORS' CONTRIBUTION}

Marindia Biffi contributed with the study concept, theoretical content, writing and review of the manuscript. Margarita Silva Diercks and Ananyr Porto Fajardo contributed with the study supervision and the review of the manuscript. Bárbara Cristina contributed with the review of the manuscript.

\section{CONFLICTS OF INTEREST}

The authors declare no conflicts of interest.

\section{ADDRESS FOR CORRESPONDENCE}

Maríndia Biffi. Avenida Presidente Vargas, 655, ap. 504, Marau, RS, Brasil. CEP: 99150-000.

E-mail: marindiabiffi@hotmail.com 


\section{ERRATUM}

On the page 1 ,

Wehre it reads:

"Bárbara Cristina"

Should read:

"Bárbara Cristina Barreiros"

Brazilian Journal of Medical Education 44 (4): e145, 2020. and reproduction in any medium, provided the original work is properly cited.

\begin{tabular}{l|l|l}
\hline 10 & REVISTA BRASILEIRA DE EDUCAÇÃO MÉDICA \\
44 (4) : el45; 2020
\end{tabular}

